\title{
A ORALIDADE E A ESCRITURA NA LITERATURA INFANTIL: REFERENCIAL TEÓRICO PARA A HORA DO CONTO
}

\author{
THE ORALITY AND THE WRITING ON CHILD LITERATURE: THEORY TO FAIRY \\ TALE TIME
}

\begin{abstract}
Clarice Fortkamp Caldin
Mestre em Literatura - Universidade Federal de Santa Catarina, 2001 Professora do Departamento de Ciência da Informação, do Centro de Ciências da Educação, da Universidade Federal de Santa Catarina e-mail: claricef@matrix.com.br
\end{abstract}

\begin{abstract}
Resumo
Aborda aspectos teóricos sobre a oralidade e a escritura. Apresenta um esboço histórico dos narradores de histórias e destaca seu papel social. Pressupõe o leitor como co-autor da obra literária. Valoriza os contos de fadas como catárticos e necessários ao desenvolvimento do psiquismo infantil. Mostra o compromisso com a verossimilhança e a visão crítica da brasilidade dos textos infantis contemporâneos. Sugere integração de bibliotecários e professores na Hora do Conto.
\end{abstract}

Palavras-chave: Oralidade e escritura; narradores de histórias; leitor; contos de fadas; literatura infantil, Hora do Conto.

\section{INTRODUÇÃO}

Apesar de persistir a polêmica oralidade/escritura, na atualidade o mundo acadêmico já considera também literatura o que tenha sido guardado pela memória coletiva. Cumpre ressaltar que a literatura percorre o trajeto da oralidade à escritura e a literatura destinada às crianças percorre idêntico caminho.

Assim, parte-se do pressuposto que literatura é, ao mesmo tempo, voz e letra. A voz se faz letra, a letra carrega a voz, que convida à leitura, que cativa o leitor. Nesse percurso, narrador, autor, leitor e ouvinte pervertem a realidade e adentram no mundo ficcional em que o imaginário é experimentado como forma de articulação entre o real e o irreal. A narração e a leitura proporcionam a apropriação da realidade do texto escrito em uma forma de entender o mundo.

É expressivo o pensamento de Erick Havelock, um estudioso moderno da questão oralidade/escritura, no argumentar que "o ser humano natural não é escritor ou leitor, mas falante e ouvinte" e a "escrita é [...] um produto da cultura, não da natureza, imposto ao 
homem natural (HAVELOCK, 1995, p.27). Propõe que o ensino da cultura escrita para a criança passe pela instrução nas artes orais, incluindo canções, danças e recitações, pois "bons leitores surgem a partir de bons falantes, capazes de recitar" (HAVELOCK,1995, p. 28).

Lembra Cecília Meireles que "não se pode pensar numa infância a começar logo com gramática e retórica: narrativas orais cercam a criança da Antiguidade, como as de hoje". Assim, "mitos, fábulas, lendas, teogonias, aventuras, poesia, teatro, festas populares, jogos, representações várias" ocuparam, "no passado, o lugar que hoje concedemos ao livro infantill". E acrescenta: “quase se lamenta menos a criança de outrora, sem leituras especializadas, que as de hoje, sem os contadores de histórias” (MEIRELES, 1984, p. 55).

Pensando nos atuais contadores de histórias - principalmente os bibliotecários que realizam a Hora do Conto - esse artigo aborda alguns tópicos que servirão como referencial teórico para um bom desempenho na atividade de narrar histórias para crianças: a oralidade e a escritura, os narradores de histórias, o leitor, os contos de fadas, e, a literatura infantil brasileira contemporânea.

\section{A ORALIDADE E A ESCRITURA}

Necessário se torna distinguir duas espécies de texto literário: o oral e o escrito. A literatura oral implica na dualidade de sujeitos - de um lado, o autor/contador e de outro, o leitor/ouvinte. A literatura escrita inscreve três elementos: a escritura, o texto e a leitura.

Ao trabalhar com a oralidade, Paul Zumthor (1979) destaca que tanto no presente como no passado existe uma poética da voz. Tal poética manifesta-se por diversas funções sociais ritualizadas pela palavra. Assim, existe a tradição da oralidade em vários aspectos da vida cotidiana, entre eles o ensino, o testemunho judiciário e a consulta médica. A transmissão oral ou a escritura da poesia oferecem problemas complexos e de natureza diversa. A poesia oral, por exemplo, não apresenta uniformidade e homogeneidade de tempo e espaço, em suas representações. A transmissão oral, mesmo quando repousa em um texto escrito, dá primazia ao ritmo sobre o sentido e à ação sobre a representação.

Cumpre lembrar que o escrever nasce como resposta às necessidades econômicas e religiosas dos povos e o narrar nasce como salvaguarda da memória e é fator de preservação do mito. 
A oralidade é, portanto, dinâmica, pois ao preservar o mito ela tem de se adaptar às novas circunstâncias, como fator de transmissão cultural e de valores. A oralidade é movimento.

Zumthor (1993, p. 19) aponta a razão possível da difusão da escritura na relação estreita que mantinha com a voz: quando um poeta "canta ou recita [...] sua voz, por si só, lhe confere autoridade", mas, se o "poeta ou o intérprete, ao contrário, lê num livro o que os ouvintes escutam, a autoridade provém do livro".

Zumthor (1993) enfoca outros tópicos: o preconceito que muitos intelectuais nutrem contra a existência de um texto sem escritura, a autoridade da voz e a importância do efeito vocal (do jogral, contador, leitor) sobre o ouvinte.

Outros teóricos afirmam que as literaturas orais baseiam-se em fórmulas, os temas são tradicionais e a estrutura é uniforme. Tal afirmativa pode passar a idéia de que a oralidade é estática e conservadora - o que não corresponde à verdade. Assim, bastaria ao narrador conhecer a fórmula e usar de improvisação para adaptações necessárias, seja ao público, seja à região, não prescindindo dos gestos, fator essencial da comunicação oral. $\mathrm{Na}$ realidade, o narrador, ao liberar sua imaginação, inova e recria velhos contos e /ou relatos. O narrador cativa seu público - que está presente e é visível..

A figura do narrador oral, contudo, está se esmaecendo na atualidade, pois como diz Walter Benjamin (1994, p.200-201), cada vez diminui o elenco de pessoas quem sabem narrar: "a arte de narrar está definhando porque a sabedoria - o lado épico da verdade - está em extinção". Isso se apresenta como uma perda, pois os narradores sempre se constituíram em fonte por excelência dos escritores. O Autor considera a narrativa "uma forma artesanal de comunicação", argumentando que "se os camponeses e os marujos foram os primeiros mestres da arte de narrar, foram os artífices que a aperfeiçoaram” (BENJAMIN, 1994, p. 205,199).

Observa-se uma diferença entre o narrador oral de Benjamin e o intérprete oral de Zumthor: o primeiro fala em narração e o segundo, em performance. Nesse sentido, o relato oral leva vantagem sobre a escritura, que presume um leitor, mas não o garante. Por outro lado, o texto escrito, que se individualiza pelo estilo do autor, concede liberdade de interpretação ao leitor Enc. Bibli: R. Eletr. Bibliotecon. Ci. Inf., ISSN 1518-2924, Florianópolis, Brasil, n.13, p.25-38, 2002. 
sem imposição de sentido. A performance também é individual, mas o intérprete pode manipular a recepção, pois não há o distanciamento do texto escrito.

Quando o discurso se torna texto, assevera Paul Ricoeur (1977), altera-se a referencialidade, pois a escrita consegue abolir a realidade, indo além dela ao criar com uma linguagem diferenciada da cotidiana o mundo do texto e ao transformar o fictício em real para o leitor, que, por sua vez, o apreende pela subjetividade. Na passagem da fala à escritura, o texto ganha autonomia, pois "não coincide mais com aquilo que o autor quis dizer" e deve “descontextualizar-se de maneira a deixar-se recontextualizar numa nova situação: é o que justamente faz o ato de ler"'(RICOEUR, 1977, p.53)

Portanto, entre a escritura e a leitura há o distanciamento e a liberdade do leitor ao fazer uso da interpretação para completar o texto. O discurso oral, por sua vez, apresenta o distanciamento em menor grau, uma vez que o narrador pela entonação da voz, pelos gestos e pela forma de conduzir a narrativa, condiciona o ouvinte ao entendimento do narrado. Em contrapartida, o texto oral é sempre aberto à participação do ouvinte porque essa é a essência da oralidade. O texto oral pode ser diferente a cada vez que for narrado, pois a recriação e a invenção fazem parte dele.

\section{OS NARRADORES DE HISTÓRIAS}

O escritor de textos literários para crianças, ocupa, atualmente, o lugar dos contadores de histórias dos primórdios da humanidade e da Idade Média, período marcado, sobretudo, pela oralidade, pela sedução das palavras e pela fruição dos sons encantatórios.

Cecília Meireles (1984, p. 49) tem razão quando diz que "o gosto de contar é idêntico ao de escrever", "os primeiros narradores são os antepassados anônimos de todos os escritores" e "o gosto de ouvir é como o gosto de ler".

De acordo com Walter Benjamin (1994, p. 198), “entre as narrativas escritas, as melhores são as que menos se distinguem das histórias orais contadas pelos inúmeros narradores anônimos". 
Sabe-se que nas sociedades primitivas, os contadores de histórias eram muito respeitados, pois se reputavam como a memória da comunidade. Assim atuavam também os jograis, na Idade Média, informadores em potenci al.

Paul Zumthor (1993, p.56) destaca o papel social dos jograis que têm "sua longínqua origem na tradição dos cantores germânicos, a qual se confunde com a dos músicos e atores da antiguidade romana". Atuando como cantores, intérpretes de poesias, contadores de histórias ou leitores, pronunciavam "uma palavra necessária à manutenção do laço social, sustentando e nutrindo o imaginário e confirmando os mitos", revestidos de "uma autoridade particular, embora não claramente distinta daquela que assume o discurso do juiz, do pregador, do sábio" (ZUMTHOR, 1993, p. 67).

Através dos jograis a palavra poética era vocalmente transmitida, "reatualizada, reescutada, mais e melhor do que teria podido a escrita" e favorecia" a migração de mitos, de temas narrativos, de formas de linguagem, de estilos, de modas, sobre áreas às vezes imensas". Os jograis afetaram "profundamente a sensibilidade e as capacidades inventivas de populações, que, de outro modo, nada teria aproximado". (ZUMTHOR, 1993, p. 71).

Além dos jograis (na maioria, homens), as mulheres também desempenharam um papel destacado como contadoras de histórias e como fortalecedoras do laço social.

No historiar os narradores de histórias, Marina Warner (1999) traça sua trajetória desde a tecelã, a feiticeira, a velha mexeriqueira, a literata - vozes femininas, ao escritor, compilador, cineasta, psicólogo e terapeuta - vozes masculinas. Ao apontar o papel ímpar das mulheres na narração de histórias, resgata a tradição da Sibila, profetisa do oráculo no templo de Apolo, que, diante da expansão da cristandade, esconde-se em uma gruta e pratica suas artes mágicas, uma delas, a de contar histórias de fadas. Tais contos, tidos por muitos como "conto das velhas", "conto das avós", "contos das fiandeiras", denotam a luta das mulheres para expressarem sua opinião em uma sociedade tipicamente masculina.

Warner (1999) esclarece que os ditados populares na Europa enfocam os gansos como criaturas emblemáticas de mulheres mexeriqueiras. Além disso, o ganso era associado com funções inferiores, realizadas por mulheres. Também, o verbo francês cacarder significa tanto a conversa das mulheres como o grito dos gansos. É pertinente, portanto, a escolha de Enc. Bibli: R. Eletr. Bibliotecon. Ci. Inf., ISSN 1518-2924, Florianópolis, Brasil, n.13, p.25-38, 2002. 
Charles Perrault em colocar no frontispício de seu livro Histoires ou Contes de Temps Passé, avec les Moralités, em 1697,o subtítulo Contes de ma Mère l'Oye [Contos da Mamãe Ganso].

Os contos de fadas são também chamados Contes de la cigogne, ou "contos para passar o tempo", atribuídos às quenouilles, fiandeiras que se reuniam para contar histórias enquanto trabalhavam nas rocas de fiar.

Sabe-se, também, que foram mulheres de camadas sociais diferentes as inspiradoras dos escritos folclóricos e infantis coletados pelos Irmãos Grimm, pois a elas cabia dominar a rede doméstica de informação.

Lembra Warner (1999, p.77) que "se as académies, que controlavam a palavra escrita, eram dominadas por autores e pensadores do sexo masculino", os salões, "as ruelles eram a esfera das mulheres, onde presidiam a palavra falada e seus usos".

Assim, nos salões da corte francesa do Ancien Régime, as mulheres organizavam sua sessão de mexericos, ouviam e contavam histórias. A narração de histórias agia, dessa forma, como um agente de ligação social e os contos de fadas eram transmitidos em voz alta, socializados pelo grupo.

Walter Benjamin (1994) afirmou que a arte de narrar está morrendo. Contudo, pode-se dizer que essa tradição está sendo resgatada quando bibliotecários realizam a Hora do Conto, pois, ao dizer um texto em voz alta, assumem o papel das fiandeiras e dos jograis.

O contador de histórias resgata a tradição oral e ao mesmo tempo estimula a imaginação do ouvinte. A mensagem é auditiva e não visual. Contar histórias é uma arte: é necessário captar o ritmo e a cadência dos contos, fazer as pausas no momento certo, não entrar em descrições cheias de detalhes, criar um clima de envolvimento e de encanto, e, acima de tudo, usar todas as modalidades e possibilidade da voz - sussurrar, imitar os ruídos, as vozes dos animais, as inflexões que indicam suspense e clímax. A narração inicia-se com a senha mágica, que indica a saída do mundo real para o mundo ficcional: Era uma vez...; e deve acabar com um refrão que indica o retorno à realidade: E assim acabou a história. Entrou por uma porta, saiu por outra. Quem quiser que conte outra. 
A narração implica em uma química entre aquele que narra e o que escuta. O narrador conduz a narrativa, encaminha o ouvinte a um universo encantado, elabora sua história dependendo do público. Nenhuma história, portanto, é igual ao modelo, posto que é reformulada a cada narração. Não existe mais a pureza do relato oral original, pois o material dos contos de fadas vincula-se ao texto impresso e modifica-se a cada narração. Voz e letra se entrelaçam para seduzir o ouvinte e o leitor.

\section{O LEITOR}

A oralidade e a escritura convivem lado a lado no lar, na escola e no lazer. Assim, "contação" e leitura complementam-se para estimular o gosto pelo literário.

Cumpre lembrar que estamos vivendo na terceira fase da história da moderna teoria literária: a da preocupação com o leitor. É ele que dá sentido ao texto escrito. Não mais interpreta o texto, mas, o recria. No dizer de Umberto Eco (1994, p.118), "ler é como uma aposta. Apostamos que seremos fiéis às sugestões de uma voz que não diz explicitamente o que está sugerindo".

Wayne Booth (1980) afirma que ao narrador/escritor confere-se uma autoridade artificial de conhecer o que vai na mente e no coração da personagem. A narrativa primitiva sempre teve um contar autoritário em que o autor manipulava os juízos do leitor, por apresentar de modo favorável ou desfavorável as personagens, de modo a despertar simpatia ou desprezo. Tal retórica direta e autoritária, como a encontrada em Homero (que está presente em suas epopéias), vai sendo substituída da ficção moderna. O narrador não intervém diretamente na história, pois não realiza uma avaliação explícita da conduta das personagens.

Assim, a voz do autor de ficção vai cedendo lugar à voz do leitor. O escritor não traduz toda a realidade externa transposta para o livro. Fica a cargo do leitor, preencher, pela sua imaginação, as lacunas do texto literário. De fato, ao se apossar dessas lacunas, o leitor penetra no universo ficcional. Como diz Umberto Eco (1994, p. 9), "todo texto é uma máquina preguiçosa pedido ao leitor que faça uma parte do seu trabalho". 
Partindo do pressuposto que o leitor não é um sujeito passivo, não é um intérprete do texto e um mero decodificador, mas um co-autor da obra literária, ele pode ou não aceitar as sugestões ou imposições sutis ou explícitas no texto. A criança, contudo, posto não ter ainda plenamente desenvolvida sua capacidade de crítica, é um alvo fácil das ideologias contidas tanto no texto quanto na ilustração. Isso explica a constante preocupação com a qualidade dos textos literários direcionados à infância.

Existe, é certo, material de leitura que pode ser considerado nocivo, pois não privilegia a fruição e não permite a reflexão crítica. Da mesma forma a leitura, quando se transforma em ato mecânico, perde a sua capacidade de estimular intelectual e emocionalmente a criança.

A leitura deve, pois, configurar-se como um jogo entre emissor e receptor em que ambos deixam marcas no texto. Leitura implica incorporar o conhecido ao desconhecido; somar a experiência anterior a descobertas novas, conduzindo a questionamentos. Assim, ler é um processo contínuo, um projeto que nunca se completa, pois a cada texto lido estamos reaprendendo a ler.

\section{OS CONTOS DE FADAS}

Segundo Walter Benjamin (1994, p.215), “o primeiro narrador é e continua sendo o narrador dos contos de fadas". Marina Warner (1999, p. 449) completa esse pensamento ao dizer que "os narradores dos contos de fadas sabem que um conto, para cativar, deve levar os ouvintes ao prazer, ao riso ou às lágrimas" pois, "se falharem, ninguém mais irá querer ouvir suas histórias".

Os contos de fadas são sempre atuais, muito embora estejam atrelados à realidade sócioeconômica da Europa medieval. Satisfazem porque mapeiam impulsos e temores conscientes e inconscientes e delineiam experiências reais. Lidam com problemas universais, atacam idéias preconcebidas e defendem causas perdidas. A curiosidade, embora castigada, é incentivada. Mostram o despertar erótico, a iniciação sexual, a esperteza e a malícia. São feministas, abrindo espaço para a mulher comunicar suas idéias. Ao mesmo tempo que defendem aspirações tradicionais, minam estes ensinamentos convencionais. Desafiam idéias estabelecidas e levantam questões na mente do público. Apresentam uma justiça poética: o filho mais novo, mais tolo, mais desvalorizado pela família e pela comunidade é quem se casa Enc. Bibli: R. Eletr. Bibliotecon. Ci. Inf., ISSN 1518-2924, Florianópolis, Brasil, n.13, p.25-38, 2002. 
com a princesa. Falam de medos, de amor, da dificuldade de ser criança, de carências, de auto-descobertas, de perdas e buscas, da vida e da morte. Alia-se a isso o fato de que os significados mudam de acordo com a necessidade ou o desejo do leitor. São sempre atuais, também, porque se envolvem no maravilhoso partindo de uma situação real; lidam com emoções; passam-se em tempo e lugar indefinidos; as personagens são simples e vivenciam situações diferentes, resolvem conflitos nos quais buscam a cumplicidade da criança através do imaginário em que bruxas e fadas atuam como elementos mágicos.

De acordo com Marina Warner (1999, p.311), “o conto de fadas, enquanto forma, lida com limites" e tais limites são "muitas vezes impostos pelo medo: um de seus temas fundamentais trata de um protagonista que parte para descobrir o desconhecido e vence seus temores".

Lembra Fany Abramovich (1995, p. 120) que "por lidar com conteúdos da sabedoria popular, com conteúdos essenciais da condição humana, é que esses contos de fadas são importantes, perpetuando-se até hoje".

Atualmente a psicanálise e os estudos das manifestações culturais contribuem para o renascimento do interesse pelos contos de fadas. Diz Marina Warner $(1999$, p.453) que "após a guerra de 1939-45, a aprovação psicanalítica dos contos de fadas como sendo altamente terapêuticos e educativos [...] sem dúvida contribuiu para esse retorno à respeitabilidade, e daí a fruição, de reinos encantados ilusórios".

Em que pesem as críticas que recebem: serem mentirosos, materialistas e conterem terror explícito, nessa época de dúvidas e incerteza que é a Pós-Modernidade, observa-se uma tendência a buscar de novo a fantasia com sentido compensatório, que proporcione uma experiência catártica. Em que pesem, também, todas as possíveis interpretações dos contos de fadas - historiográficas, psicanalíticas, religiosas, voltadas para os rituais da colheita, fases da lua, ritos de iniciação ou de passagem - o objetivo desse artigo é proporcionar suporte teórico de sua validade para aplicação na Hora do Conto.

Segundo Bruno Bettelheim (1980), os contos de fadas são os mais indicados para ajudar as crianças a encontrar um significado na vida, pois, ao estimular a imaginação, desenvolver o intelecto, harmonizar-se com suas ansiedades e tornar claras suas emoções, são enriquecedores, satisfatórios e ajudam a aliviar as pressões conscientes e inconscientes. Enc. Bibli: R. Eletr. Bibliotecon. Ci. Inf., ISSN 1518-2924, Florianópolis, Brasil, n.13, p.25-38, 2002. 
A partir dos cinco anos, a criança percebe que os contos de fadas não fazem parte da realidade externa, mas deixa-se seduzir por eles porque se harmonizam com sua realidade interna. Ela sabe que "a verdade dos contos de fadas é a verdade de nossa imaginação" (BETTELHEIM, 1980, p.148).

É interessante repetir as palavras do terapeuta e educador: "o conto de fadas deveria ser contado em vez de lido" (BETTELHEIM, 1980, p.185). O Autor acredita que o contar favorece o envolvimento emocional.

Quando tais contos são lidos em sala de aula, pouco contribuem para as crianças porque logo dão lugar à outra atividade, diluindo-se, dessa forma, a impressão causada pela história. $\mathrm{O}$ narrar, ao contrário, possibilita que as crianças mergulhem na história e possam meditar sobre ela. A audição cria uma atmosfera de intimidade que favorece a conversação posterior, levando à reflexão e oferecendo possibilidades de enriquecimento emocional e intelectual. Cabe aos bibliotecários, na Hora do conto, explorar o catártico no maravilhoso e favorecer o desenvolvimento da sensibilidade artística da criança.

Para finalizar esse tópico, lembro as palavras de Lewis Carrol (apud BETTELHEIM, 1980, p.35): os contos de fadas são, na verdade, "um presente de amor".

\section{A LITERATURA INFANTIL BRASILEIRA CONTEMPORÂNEA}

Atualmente, a literatura direcionada à criança, conta, além dos clássicos, de textos ditos realistas. Os textos realistas, conquanto se querem diferentes dos clássicos ao substituir fadas, bruxas e fantasias por pessoas e fatos do cotidiano, também seduzem porque comunicam as vivências das crianças em uma mensagem essencialmente artística.

Não ficam imunes à crítica literária, contudo. Se os contos de fadas são considerados alienantes, os contos realistas são denominados projetos educativos, pois tratam dos problemas da sociedade tais como morte, divórcio e ecologia. Fica esquecido o fato de que a conscientização da compreensão da realidade pode acontecer pelas vias do realismo e da 
fantasia e que mesmo os textos moralizantes suscitam emoções e conduzem a aprendizagens éticas e estéticas.

Tanto os contos de fadas quanto os contos realistas falam de sofrimento e angústia, porque a dor tem a idade do homem. Não há nada mais atual do que a dor.

Se a partir dos anos setenta no Brasil, a literatura infantil passa a ser criadora e não se posiciona mais na cauda da literatura para adultos, preocupa-se cada vez mais com a competência estética do receptor. Ao inserir o protagonista criança na narrativa, provoca no leitor reações de assombro e estímulos à ação. Nos contos de fadas, o herói nada faz para mudar a sua situação; sempre é socorrido por um poder mágico. Nos contos realistas, o heróicriança está sempre em ação - questiona, refuta, age.

Em que pese o adultocentrismo (o autor adulto organiza os fatos e confere juízo de valor a eles), nas narrativas realistas as crianças são colocadas como transformadoras das situações sociais; há, portanto, um deslocamento do poder do adulto para a criança.

Além disso, há uma mudança na narrativa, que passa de segura a crítica. Como mostra Nelly Novaes Coelho (1995, p. 63), acontece

o experimentalismo com a linguagem, com a estrutura narrativa e com o visualismo do texto; substituição da literatura confiante/segura por um literatura inquietante/questionadora, que põe em causa as relações convencionais existentes entre a criança e o mundo em que ela vive; questionando também os valores sobre os quais nossa sociedade está assentada.

Parte da atual produção literária para crianças vale-se do humor como forma de subverter padrões da moralidade explicitada nos contos tradicionais. Assim, a paródia, tão comum na arte contemporânea, processa, no campo literário, a inversão dos padrões narrativos clássicos, para expressar, pelo riso e pelo bufo, a dessacralização dos valores éticos tradicionais da sociedade humana. Ao subverter padrões de comportamento social, a narrativa contemporânea inverte o ethos das personagens e repõe a oralidade das narrativas antigas na escritura carnavalizada. Nesse universo às avessas, o imaginário dos contos de fadas é substituído pelo compromisso com a verossimilhança nas histórias infantis da atualidade que 
valorizam o cotidiano. Apesar da inversão, o poder de encantamento dessas narrativas permanece.

Tais textos contemporâneos renovadores conduzem a uma visão crítica da brasilidade. Discutem a relação de poder através do recurso da paródia e do humor, quando apresentam um autoritarismo às avessas, como as histórias narradas por Ruth Rocha e Ana Maria Machado. Visto que o poder permeia todas as relações humanas, na narrativa contemporânea o poder está sempre presente porque pressiona e incomoda.

Se os contos realistas não permitem escorregar muita fantasia no texto literário, permitem, por seu turno, o espaço para fluir a imaginação da criança. Existem muitas coisas além do que a visão alcança e só é possível chegar até elas pelas vias do imaginário.

\section{CONSIDERAÇÕES FINAIS}

A leitura desempenha um papel no desenvolvimento social, econômico e político da nação, pois não existe nação desenvolvida que não seja uma nação de leitores. A nação brasileira precisa de uma massa crítica de leitores ativos, que saibam interpretar com desenvoltura as informações escritas. Restrita à informação oralizada, a grande massa da população brasileira carente, que habita as favelas e as periferias, não tem chance de incorporar-se às elites pensantes e atuantes, pois não adquiriu o direito à voz crítica. Excluído o livro didático, que é praticamente obrigatório e distribuído gratuitamente às escolas pelo Governo Federal, as crianças da classe baixa têm acesso à literatura apenas através da escola ou da biblioteca. Se a escola valorizar a leitura, mas a sociedade não o fizer, o hábito de ler extingue-se com a conclusão ou evasão do ensino fundamental (CROPANI, 1998).

A promoção da leitura, é, portanto, um problema de todos. Passa pela família, pela escola, pela biblioteca, pela comunidade e pela sociedade. Não pode ser considerada um presente do Estado, posto que é um direito do cidadão.

Lembrando que o contato com a literatura infantil passa da audição e do deciframento de imagens para o domínio do código escrito proporcionado pela escola, gostaria de colocar algumas sugestões: continuidade na tradição de contar histórias para crianças, valorizando a 
Hora do Conto; recuperação do estatuto da liberdade e de prazer da leitura no âmbito das escolas; permitir à criança ser sujeito em suas leituras; oportunizar à criança o contato não apenas com autores diferentes, mas com vários livros do mesmo autor em épocas diferentes de sua vida; propiciar à criança a construção de um novo texto; integração de professores e bibliotecários na elaboração de programas de leitura e de "contação" de histórias mesclando os contos de fadas com os textos realistas na Hora do Conto; criação de uma política de fomento às bibliotecas escolares; apoio das universidades às pesquisas relacionadas com os processos de leitura e o resgate à oralidade, e, por fim, aventar a possibilidade de a sociedade brasileira organizar um programa permanente de propaganda da leitura e da narração de histórias para crianças.

\begin{abstract}
Research on theoretical aspects of orality and writing. It presents a historical sketch of the narrators of tales and detaches the social function performed by the reader as co-author of tales. It increases the value of fairytales as cathartic and important to the development of the child psychism. It shows the commitment and the critic vision of Brazilian contemporary fairytales. It suggests an integration of librarians and teachers at the fairytale time.
\end{abstract}

Key words: orality; writing; narrators of tales; readers; fairytale time.

\title{
8 REFERÊNCIAS BIBLIOGRÁFICAS
}

ABRAMOVICK, Fanny. Literatura infantil: gostosuras e bobices. São Paulo: Scipione, 1995.

BENJAMIN, Walter. Magia e técnica, arte e política: ensaios sobre literatura e história da cultura. Tradução de Sérgio Paulo Rouanet. 7.ed. São Paulo: Brasiliense, 1994.

BETTELHEIM, Bruno. A psicanálise dos contos de fadas. Tradução de Arlene Caetano. Rio de Janeiro: Paz e Terra, 1980.

BOOTH, Wayne. A retórica da ficção. Tradução de Maria Teresa Guerreiro.Lisboa: Arcádia, 1980.

COELHO, Nely Novaes. Dicionário crítico da literatura infantil e juvenil brasileira: séculos XIX e XX. 4.ed. ampl. São Paulo: Ed.USP, 1995.

CROPANI, Ottaviano De Fiori di. Livro, biblioteca e leitura no Brasil. Disponível em:

$<$ http://mine.gov.br/textos> Acesso em: 12 ago. 1998.

ECO, Umberto. Seis passeios pelos bosques da ficção. Tradução de Hildegard Feist. São Paulo: Companhia das Letras, 1994.

Enc. Bibli: R. Eletr. Bibliotecon. Ci. Inf., ISSN 1518-2924, Florianópolis, Brasil, n.13, p.25-38, 2002. 
HAVELOCK, Eric. A equação oralidade-escritura: uma fórmula para a mente moderna. In: OLSON, David; TORRANCE, Nancy. Cultura e oralidade. Tradução de Valter Lellis Siqueira. São Paulo: Ática, 1995. p. 17-34.

MEIRELES, Cecília. Problemas da literatura infantil. 3.ed. Rio de Janeiro: Nova fronteira, 1984.

RICOEUR, Paul. Interpretação e ideologia. Organização, tradução e apresentação de Hilton Japiassu. Rio de Janeiro: F. Alves, 1977.

WARNER, Marina. Da fera à loira: sobre contos de fadas e seus narradores. Tradução de Thelma Médici Nóbrega. São Paulo: Companhia das Letras, 1999.

ZUMTHOR, Paul. A letra e a voz: a literatura medieval. Tradução de Amalio Pinheiro, Jerusa Pires. São Paulo: Companhia das Letras, 1993.

ZUMTHOR, Paul. Pour une poétique de la voix. Poétique, Paris, n. 40, p. 514-524, nov. 1979. 